\title{
Suprasegmentally Feature of Intonation in English Debate: A Praat Analysis
}

\author{
Wulan Rahmatunisa ${ }^{1}$, Syahrul Syarifudin ${ }^{2}$ \\ ${ }^{12}$ Universitas Kuningan, Indonesia \\ \{1wulan.rahmatunisa@uniku.ac.id, ${ }^{2}$ syahrul.syarifudin@uniku.ac.id\}
}

\begin{abstract}
This research focuses on analyzing intonation as the element of suprasegmentally by using PRAAT program. The data was taken from the English debate competition involving college students. The English debate demands that students not only be able to express ideas in English, but also require students to be able to master global knowledge, analyze, make judgments, and convince the public. This makes suprasegmentally study in the debate discourse is important to be investigated. The present study employs descriptive qualitative approach. PRAAT program version 6.0.33 is used to analyze intonation patterns. The results show that the pressure and intonation in the speech is caused by a factor of the situation which semantically can create differences in meaning. It is coherent with the statement from Nespor \& Vogel (2007) that semantic factors have a relation to an interest and strength, such as the level of utterance and the intonation contour style contained in the speech. In conclusion, differences in meaning in the context of discourse can occur naturally depending on the situation of the speech.
\end{abstract}

Keywords: Intonation; Suprasegmentally; PRAAT; Debate

\section{Introduction}

English debate has become a necessity for students in the academic world. The demand for mastery of global knowledge competence is one of the reasons why the English debate needs to be an academic part of students. While developing countries require the content of the English debate into their educational curriculum, Indonesia needs to continue to make the English debate as part of academic study, in any form. The English debate demands that students not only be able to express ideas in English, but also require students to be able to master global knowledge, analyze, make judgments, and convince the public. In English debates, students will be confronted with real problems faced by a society or nation. Students must be able to position and convince the public that their position is right and right. Therefore, the English debate is the right media in practicing student negotiation and argumentation skills on an international scale. It is appropriate if educational institutions in Indonesia carry out English debate competitions between students in the context of internalizing the spirit of a positive competition that contains demands for communication and argumentation skills.

Debates not only convey a series of words or sentences, but also the meaning behind each utterance phonologically. Basically, debate is one part of language skills that are used systematically to accomplish or achieve certain goals (Abidin, 2013, p. 96). In practice, the expression of debate is not only reflected in body language, but also in the phonological systematics of speech. The phonological aspect is called suprasegmentally, namely phoneme sound that is influenced by speech, pressure, and intonation. Muslich (2008) describes the 
suprasegmentally aspects related to speech or sound segments (phonemes), namely tone, pressure, joints, intonation. Then, Kridalaksana (2009) said that suprasegmentally morphemes occur from segmental phonemes, such as phonemic pressures, tones, or pauses. Furthermore, Nespor and Vogel (2007) stated that suprasegmentally or prosody is an aspect that must be included in phonology. It means suprasegmentally study is the domain of phonological area that in the discourse is intended to examine the production of meaning or ideology.

In mastering debate as a means to sharpen communication and argumentation skills, an understanding of the use of intonation is needed, which is one of the important suprasegmentally elements. Intonation is very instrumental in distinguishing sentence intentions (Muslich, 2008). Differences of intonation, pressure, or the tone of the teaching of a morpheme in the text can bring different meanings if those are spoken in different ways so that phonological speech is strongly influenced by the context of speech, in this case the context of discourse. Suprasegmentally is something that accompanies the phoneme, which can be in the form of sound pressure (intonation), long-short (pitch), and sound vibrations that indicate certain emotions. Suprasegmentally is the element that "accompanies" and influences the sound of language, and not the true sound. Suprasegmentally elements are also called prosody (Muslich, 2008: 81). In contrast to Marsono (1999: 115) suprasegmentally sounds are sounds that accompany segmental sounds. Verhaar (2010: 55) explains that the suprasegmentally sounds include intonation, tone, accent and pressure. In fact, the phonetic description of suprasegmentally sounds is only the basis for a phonemic description. However, in many ways the phonetic and phonemic aspects are not easily distinguished. The easiest way to understand the suprasegmentally element is through an acoustic phonetic approach. There are two acoustic properties that influence the suprasegmentally elements, namely frequency and amplitude. These two elements are very influential in the suprasegmentally elements and they are very related.

The difference between the two sounds is based on whether or not the sound is segmented. Sounds that can be segmented, like all vocal and consonant sounds are segmental sounds. While sounds or elements that cannot be segmented, accompanying segmental sounds, such as pressure, tone, pause and duration (elongation) are called suprasegmentally or non-segmental sounds or elements (Chaer, 2013: 35).

\section{Methodology}

This research was conducted in a qualitative design because it investigated the phenomenon, which is described by Cresswell (1994) as an approach that often makes knowledge claims based on constructivist perspectives. Researchers physically come to people, settings, sites or institutions to be interviewed or recorded in their natural settings. Qualitative research tends to be an attempt to produce situational descriptions and interpretations of phenomena that researchers can offer to coworkers, students, and others to modify their own understanding of phenomena (Stake, 2010). This technique allows researchers to share in the understanding and perceptions of others and to explore how people arrange and give meaning to their daily lives. Therefore, as Nunan (1993) said, the data involved in qualitative research tends to be in the form of words, pictures, diagrams, etc., not numerical ones. This does not mean that qualitative research cannot contain numerical data at all. Sometimes numerical data can be in qualitative research such as frequency and percentage (Emilia, 2000).

The research data was taken from the English-language debate competition held at the university level, which is held by the Ministry of Research, Technology and Higher Education 
called NUDC (National University Debating Championship). The system used in NUDC is the British Parliamentary (BP) system. This system is a system used in the World University Debating Championship (WUDC) or a debate competition among world-level tertiary institutions. This research data is in the form of recorded speech and field notes. Data collection activities are divided into three stages, namely data collection procedures, data transcripts, and coding. Raw data in the form of audio recordings combined with field notes are transcribed into data transcription sheets. Data collection procedures with qualitative methods include:

a. Setting boundaries for research, which leads to the classification of participants in certain areas.

b. Gathering information through observation, and

c. Establishing protocols for recording information.

In analyzing data, the first step is transcribing from the recorded sound. Then the transcription data that contains phonetic copies in the form of English spelling along with the tone spoken by the subject is processed into a graphic PRAAT. PRAAT program version 6.0.33 is used to analyze intonation patterns. PRAAT is a program created by Paul Boersma \& David Weenink of the University of Amsterdam's Phonetic Sciences Department (www.praat.org). With the slogan 'doing phonetics with computer', PRAAT is a software for flexible sound analysis and reconstruction. PRAAT can be used to do many things, from spectrogram analysis to sound reconstruction itself and making diagrams or drawings that can be used in scientific work. The PRAAT program is highly needed by researchers who use acoustic data. Accurate and complete acoustic information can be generated by empowering the PRAAT Program. The spelling used is IPA phonetic spelling. As said by Miles \& Huberman (1992: 87), that the data scattered across various utterances can be analyzed, the usual method used as a solution is to give a code to the observational field notes. Code numbers, subjects, and types of sentences are written in the data transcription sheet.

\section{Result and Discussion}

The suprasegmentally element in the form of intonation affects the meaning of the sentence. In fact, on the basis of this intonation-pattern study, sentences are divided into declarative, interrogative sentences, and command sentences (imperative) (Muslich, 2008). The variations in tone patterns in sentence intonation can be represented by Arabic numerals $(1,2,3)$ or lines. Declarative sentences are characterized by a flat-down intonation pattern. This declarative sentence is a sentence that tells an event, reveals something, or comments on something. Usually informs the listener something new. This declarative sentence can still be distinguished into several kinds, the most important thing is that it must contain a word that functions to tell something, which describes something, which describes something, and which comments on something. Here are some sentence patterns in English debate that have been analyzed using the PRAAT application. 


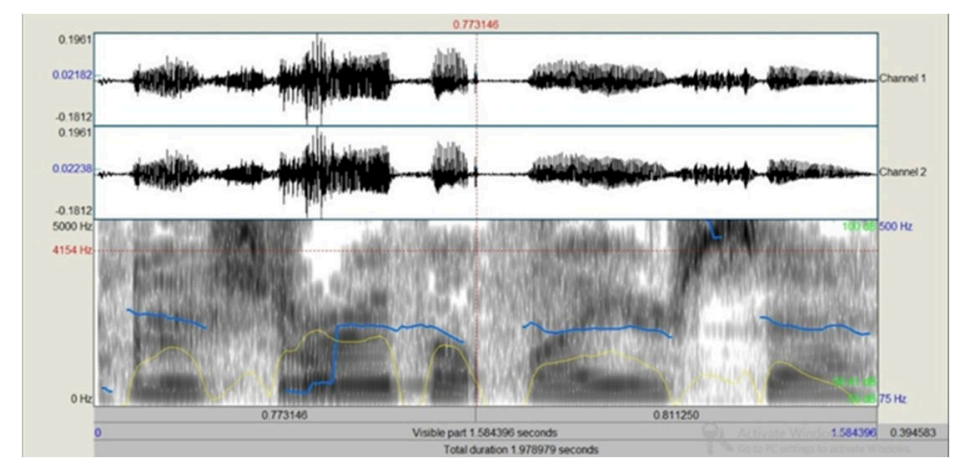

Fig 1. PRAAT Analysis of Declarative Sentence

Figure 1 shows the result of PRAAT analysis for declarative sentence. A declarative sentence is a sentence which tells something to the listener so that it is called a statement sentence. In spoken language, this declarative sentence is marked with a decreasing tone, while in written language it is marked by the end of the sentence with a period. Declarative sentences can be in the form of active-passive sentences, direct-indirect sentences, singlecompound sentences, and so on, as long as they constitute news. Declarative sentences have various purposes based on their use, namely as notifications, reports, expectations, requests, introductions, invitations, and so on. In English debates this sentence pattern is widely used because the purpose of the speaker is to present arguments, convince listeners, and function of persuasion.

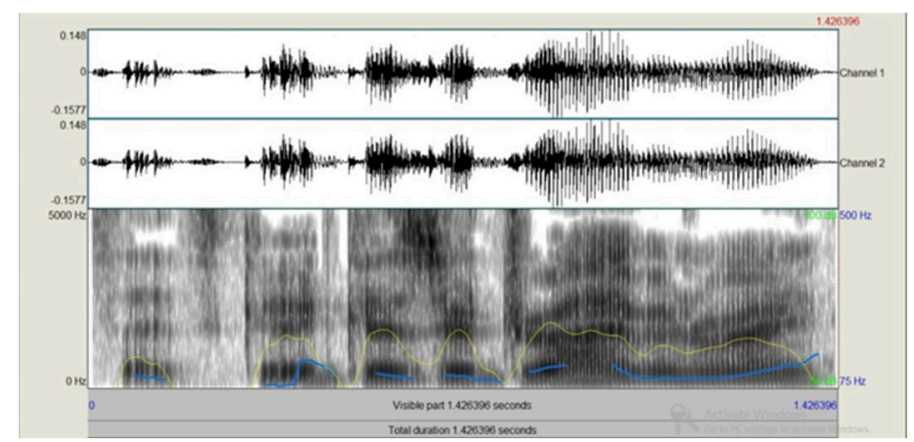

Fig 2. PRAAT Analysis of Interrogative Sentence

Figure 2 shows the PRAAT analysis for interrogative sentence patterns. An interrogative sentence is a sentence whose content is asking something or someone, that is what is called an interrogative sentence. Ways that can be used to make interrogative sentences include; adding the word 'auxiliary do' to the question word, such as "Do you know who prepare this report"; by reversing the order of words and adding particles - is it, like "got the chair yesterday?"; use question tags or tail questions, such as "the price is expensive, isn't it?"; change the intonation of sentences, such as "They like it. ---> They like it?"; and by using question words $5 \mathrm{~W} 1 \mathrm{H}$, such as "Why don't you go to school?". From the data found, there is a small portion of the use of interrogative sentences in English debates. The form is not in the perfect grammatical structure of the interrogative sentence but by changing the intonation of the sentence. This is 
because in spoken language the grammatical structure is not too emphasized as long as the listener can grasp the meaning of what is being said.

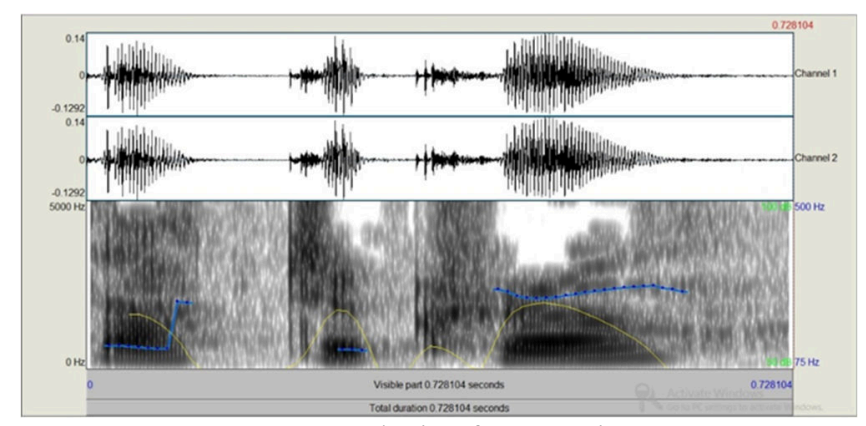

Fig 2. PRAAT Analysis of Imperative Sentence

Figure 3 shows the imperative sentence pattern. An imperative sentence is a sentence whose meaning is to give an order to do something called a command sentence. In written language, a command sentence is marked with an exclamation point (!), While in spoken language it is marked by an increase in the tone at the end of the sentence. The characteristics of a command sentence include using a non-transitive verb; use words, such as please, try, please to smooth a command sentence; and if the command sentence means prohibition, it is usually preceded by the word do not. The foundation in an intonation is the existence of a series of notes colored by pressure, duration, stops, and an attractive, even, low voice at the end of the flow of speech. In this stop, if in a flat voice, it will end with a period (.), So that it becomes a news sentence. If the sound goes up and ends with a question mark (?), It will be a question sentence. Meanwhile, if the sound goes up and ends with an exclamation point (!), It will be a command sentence. The following is a classification table for sentence types in an English debate based on intonation and stress patterns.

Table 1. Classification of Sentence Types in Debating

\begin{tabular}{cccc}
\hline No. & Sentence Types & Occurrence & Percentage \\
\hline 1. & Declarative & 54 & $75 \%$ \\
2. & Interrogative & 15 & $21 \%$ \\
3. & Imperative & 3 & $4 \%$ \\
\hline & Total & 72 & $100 \%$ \\
\hline
\end{tabular}

Based on the table above regarding the analysis data on sentence patterns in English debate using the PRAAT application, the dominant sentence is the declarative sentence. From the total of 72 utterances analyzed, 54 were classified as declarative sentences, 15 were classified as interrogative utterances, and 3 other utterances were classified as imperative sentences. This means that in a debate the essence of maintaining the majority-built argument through declarative sentences. Declarative sentences become the most dominant pattern because debate is a discussion or exchange of opinions about something by giving reasons to defend each other's opinions. Declarative sentences are characterized by a flat-down intonation pattern. This proves the theory presented by Halliday and Greaves (2008) which states that when someone conveys information using declarative sentences, the intonation pattern will decrease, while when someone asks a question, the intonation pattern will increase. 


\section{Conclusion}

The results of this study identified three types of sentences found in debating based on intonation patterns. They are declarative, interrogative, and imperative. Declarative sentences become the most dominant pattern used in debating because debate is a discussion or exchange of opinions about something by giving reasons to defend each other's opinions. In English debates this sentence pattern is also widely used because the purpose of the speaker is to present arguments, convince listeners, and function of persuasion. It is hoped that the results of this study can enrich the literature on suprasegmentally elements of phonological studies which still have little attention in the context of Indonesian EFL. Practically, this study provides information related to improving communication skills and expressing arguments especially for students. Professionally, through the results of this research, it is hoped that teachers and lecturers can develop debate strategies that combine suprasegmentally element analysis to support student success in mastering English as a foreign language.

\section{References}

[1] Abidin, Y. Z. (2013). Pengantar Retorika. Bandung: Pustaka Setia.

[2] Afriani, S. H. (2015). Analisis Uji Persepsi: Intonasi Kalimat Perintah Bahasa Indonesia oleh Penutur Bahasa Jepang. Tamaddun Vol. XV, No. 1/Januari - Juni 2015

[3] Alwi, H., S. Darjowjidojo, H. Lapoliwa, \& A.M. Moeliono. (2003). Tata bahasa baku bahasa Indonesia. Jakarta: Balai Pustaka.

[4] Bolinger, D. (editor). (1972). Intonation. Middlesex England: Penguin Books Ltd.

[5] Chaer, A. (2013). Fonologi Bahasa Indonesia. Jakarta: PT Rineka Cipta.

[6] (2007). Linguistik Umum. Jakarta: PT Rineka Cipta.

[7] Creswell, J. W. (1994). Research design qualitative and quantitative approaches. London: Sage Publisher.

[8] Emilia, E. (2000). Research method in education: Hasil pemikiran. Bandung: Indonesia University of Education.

[9] Hart, J.'t., R. Collier \& A. Cohen (1990). A Perceptual study of intonation. Cambridge: Cambridge University Press.

[10] Kridalaksana, H. (2009). Kamus LinguistikEdisi Keempat. Jakarta: PT Gramedia Pustaka Utama.

[11] Lehiste, I. (1970). Suprasegmentals. Cambridge: The MIT Press.

[12] Malmberg, B. (editor). (1974). Manual of phonetics. Amsterdam: North-Holland Publishing Company.

[13] Marsono. (1999). Fonetik. Yogyakarta: Gadjah Mada University.

[14] Miles, M. B. \& Huberman, A. M. (1992). Analisis Data Kualitatif. Jakarta: Universitas Indonesia

[15] Muslich, M. (2008). Fonologi Bahasa Indonesia Tinjauan DeskriptifSistem Bunyi Bahasa Indonesia. Jakarta: Bumi Aksara.

[16] Nespor, M. \& Vogel, I. (2007). ProsodicPhonology with A New Foreword 2nd. Berlin: Mouton.

[17] Nunan, D. (1993). Research Method in Language Learning. Cambridge: Cambridge University Press.

[18] Octavia, W. (2018). Penamaan bunyi segmental danSuprasegmental pada pedagangKeliling. 
Jurnal Bahasa Lingua Scientia, Vol. 10, No. 1, Juni 2018

[19] Pike, K. L. (1945). Intonation of American English. Ann Arbor: University of Michigan.

[20] Stake, R.E. (2010). Qualitative Research: Studying How Things Work. New York: The Guilford Press

[21] Van, H., Vincent, J., \& Judith, H. (2001). "Temporal Distribution of Interrogativity Marker in Dutch: A Perceptual Study". Dalam Gussenhoven, Carlos, T. Rietveld, and N. Warner (eds.). 2001. Papers in Laboratory Phonology VIII. Cambridge: Cambridge University Press.

[22] Verhaar, J. W. M. (2010). Asas-Asas Linguistik umum. Yogyakarta: Gadjah Mada University Press.

[23] Yusuf, S. (1998). Fonetik dan Fonologi. Jakarta: Gramedia Pustaka Utama. 